\title{
BIOREMEDIATION OF HEAVY METALS FROM ENVIRONMENT BY BACTERIA
}

\author{
Javaneh Moghavi* \\ "Islamic Azad University, Department of Natural Resources, MSc of Environmental Management, \\ Bandarabas Branch, Bandarabas, Iran; \\ *Corresponding Author Javaneh Moghavi, e-mail: moghavi@aftermail.ir;
}

Received January 2020; Accepted March 2020; Published April 2020;

DOI: https://doi.org/10.31407/ijees10.215

\begin{abstract}
The increasing progress of industries in the last decade has been the most important cause of environmental pollution, and the polluted wastewater from various industries is causing large amounts of heavy metals to enter the environment. The global level of environmental pollution of metals has increased dramatically in the last two centuries. The presence of toxic densities of metals in the environment has detrimental effects on human and animal health and disrupts ecosystem balance and order. Therefore, it is essential to study the ways of removing these pollutants. Bioremediation, where bacteria are used to detoxify and degrade environmental pollutants, is a viable alternative to current physico-chemical strategies for the removal of heavy metals. Therefore, this study aimed to investigate the bioremediation of heavy metals from environment by bacteria was conducted. Various physical, chemical and biological methods have been used to remove heavy metals, including the use of biodegradable process because of the economically feasible method of removing many of the heavy metals using a series of low value materials. Biosorbent is the physical and chemical uptake of heavy metals by living and non-living microorganisms (bacteria, fungi, algae) and other organisms (such as rice bran, fruit bark, leaves and trees, etc.). Biosorption is a new technology that utilizes inactive or dead biomass to remove heavy metals from aqueous solution. The use of bacteria by bioremediation processes for the treatment of wastewater containing heavy metals does not have many of the major limitations of other physico-chemical methods and is more economically desirable . However, further studies are needed to address the current limitations of this technology for use on a practical scale.
\end{abstract}

Keywords: bioremediation, heavy metals, bacteria, biosorbent 